\title{
Use of PCR-RFLP Analysis to Monitor Fungicide Resistance in Cercospora beticola Populations from Sugarbeet (Beta vulgaris) in Michigan, United States
}

\author{
N. Rosenzweig, Department of Plant, Soil and Microbial Sciences, Michigan State University, 612, Wilson Road, 35 Plant Biology \\ Building, East Lansing, MI 48824, USA; L. E. Hanson, Department of Plant, Soil and Microbial Science, and United States Depart- \\ ment of Agriculture Agricultural Research Service, 1066 Bogue Street, Room 494, East Lansing, MI 48824, USA; G. Clark, Michigan \\ Sugar Company, Euclid Road, Bay City, MI 48706, USA; G. D. Franc and W. L. Stump, Department of Plant Sciences, University of \\ Wyoming, Laramie, WY 82071; Q. W. Jiang, Department of Plant, Soil and Microbial Sciences, Michigan State University; \\ J. Stewart, Michigan Sugar Company; and W. W. Kirk, Department of Plant, Soil and Microbial Sciences, Michigan State University
}

\begin{abstract}
Rosenzweig, N., Hanson, L. E., Clark, G., Franc, G. D., Stump, W. L., Jiang, Q. W., Stewart, J., and Kirk, W. W. 2015. Use of PCR-RFLP analysis to monitor fungicide resistance in Cercospora beticola populations from sugarbeet (Beta vulgaris) in Michigan, United States. Plant Dis. 99:355362 .

Genetic resistance to Quinone outside inhibitor (QoI) and benzimidazole fungicides may be responsible for a recent decline in efficacy of chemical control management strategies for Cercospora leaf spot (CLS) caused by Cercospora beticola in Michigan sugarbeet (Beta vulgaris) fields. The target genes and fungicide resistance mutations are known for these two fungicides. Based on this, two standard polymerase chain reaction restriction fragment length polymorphism (PCRRFLP) assays were developed to detect the G143A and E198A point mutations in the fungal mitochondrial cytochrome $b$ and the $\beta$-tubulin genes, respectively. These mutations confer a high level of resistance to either QoI or benzimidazole fungicides. The presence of the G143A and E198A mutations was monitored within C. beticola populations

recovered from Michigan sugarbeet production fields collected in 2012. Both the QoI-resistant cytochrome $b$ allele and the benzimidazole-resistant $\beta$-tubulin allele were detected directly from leaf tissue following a PCR-RFLP assay. Using either detection assay, the G143A and E198A mutations were detected in over $90 \%$ of the 118 field samples originating from Michigan sugarbeet production under fungicide management programs for CLS control. Monitoring of the G143A and E198A mutations in fields located in 9 counties and 58 townships indicated that the mutations were widespread in Michigan sugarbeet production areas. The PCR-based assays used and developed in this study were effective in detecting the presence of the G143A and E198A mutations in C. beticola field populations from Michigan.
\end{abstract}

Cercospora leaf spot (CLS), caused by Cercospora beticola (Sacc.), is an annual concern for sugarbeet (Beta vulgaris L.) production in many growing regions (21). CLS is the major foliar disease on sugarbeet, especially when conditions are conducive for disease epidemics (21). Additionally, CLS can cause significant yield losses of up to $40 \%$ (21). Disease pressure is especially severe during growing seasons with high humidity and warm temperatures (above $15^{\circ} \mathrm{C}$ ) (15). Economic losses may occur due to the reduction in harvested yield and/or percentage of extractable sugars as a result of a decrease in photosynthetic capacity $(5,21)$. Moreover, storability can be reduced in beet roots with lower sugar content due to foliar infection (21). In the midwestern United States, management of CLS depends on timed fungicide applications, disease forecasting prediction models, and the use of CLStolerant sugarbeet varieties $(5,23,24,49)$. The disease is mainly controlled through application of fungicides in the field.

Quinone outside inhibiting (QoI) fungicides are important tools for disease management of many plant-pathogenic fungi, including C. beticola $(16,26,42,43)$. The mode of action is to inhibit cell respiration by binding at the ubiquinol oxidation center (Qo site) of the mitochondrial cytochrome $b c l$ complex $(2,44)$. QoI fungicides disrupt mitochondrial respiration by binding to cytochrome $b$. Pyraclostrobin and other QoIs, provide an important tool for broad-

Corresponding author: W. W. Kirk, E-mail: kirkw@msu.edu

* The $\boldsymbol{e}$-Xtra logo stands for "electronic extra" and indicates that a supplementary figure is available online.

Accepted for publication 3 September 2014.

http://dx.doi.org/10.1094/PDIS-03-14-0241-RE

(C) 2015 The American Phytopathological Society spectrum control of various plant pathogens of cereals, fruits, and vegetables (16). An experimental use permit (EUP) was granted by the Environmental Protection Agency (EPA) in 1998 for the use of pyraclostrobin in the control of CLS on sugarbeets and was subsequently registered commercially in 2002. Due to the persistent use over the past decade of pyraclostrobin and other QoI fungicides since registration for CLS and Rhizoctonia crown and root rot, the selection pressure for the development of QoI fungicide resistance imposed on $C$. beticola is quite high on sugarbeet crops in Michigan and throughout the United States. Relatively quickly after widespread commercial use of QoIs, the first report of resistance to QoI fungicides was detected in isolates of Blumeria graminis f. sp. tritici, the cause of powdery mildew in wheat collected from fields in Europe (45). Product efficacy had declined compared to earlier disease control levels in many commercial and experimental fields in Europe, and differences in pathogenic fitness between QoIresistant and -sensitive $B$. graminis isolates was not detected $(8,45)$. Subsequently, Mycosphaerella fijiensis, Venturia inaequalis, Pythium aphanidermatum, Alternaria solani, Pyricularia grisea, Colletotrichum graminicola, Sphaerotheca fuliginea, Pseudoperonospora cubensis, and Plasmopara viticola isolates resistant to QoI fungicides have been observed in commercial fields and experimental field trial sites after intensive use of QoI fungicides for many years $(1,2,8,20,28,38,40,42,43)$.

Historically in Michigan benzimidazoles were used for CLS control (48). Benzimidazoles act primarily by binding to fungal $\beta$ tubulin, thus interfering with mitosis and disrupting integrity of the fungal cytoskeleton $(11,46)$. Resistance was found in the area in the 1990s (7). Resistance to benzimidazole fungicides has been examined in a number of different filamentous fungi. Typically, tolerance to benzimidazole fungicides is due to mutations in the $\beta$ tubulin gene, which reduce the binding specificity of benzimidazole at the target site $(9,10,22,41)$. These mutations can be targeted and used to quickly and effectively identify tolerant strains with 
DNA-based methods (30). Rapid cost-effective molecular detection methods for resistant isolates are important in monitoring field populations and in the evaluation and testing of fungicide resistance management programs. In particular, the E198A amino acid substitution has been shown to be responsible for high levels of benzimidazole resistance in field isolates of many fungal species $(29,31,34,50)$.

Major issues have developed over the past few years with the introduction of effective fungicides for control of CLS related to application timing of fungicides. Of major concern is the evolution and development of insensitivity to conventional and novel fungicides in $C$. beticola populations $(3,4,19,33,48)$. There are significant economic barriers that prevent growers of sugarbeet in Michigan from using more than three fungicide applications to control CLS, and commonly only single applications are made. Recently, weather-based integrated disease management tools have been available to sugarbeet growers in Michigan to optimize fungicide application programs (BeetCast, Weather Innovations, Chatham, ON, Canada). The BEETcast prediction model was developed in Ontario, Canada for Ontario sugarbeet growers and later adapted to Michigan growers. The model measures leaf wetness and temperature and converts the information into disease severity values or DSVs. As the DSVs accumulate over time, the model predicts appropriate application timings for fungicides. One significant drawback of this approach is the tendency to apply products with a single active ingredient with a narrow mode of action (e.g., benzimidazole and QoI fungicides). This has led to the development of insensitivity to some fungicides previously recommended for control of CLS, most notably benomyl, thiophanate-methyl, and pyraclostrobin $(6,26,48)$. Additionally, Cercospora Risk Zones are another essential part in the BEETcast model in addressing the development of CLS along with tracking fungicide resistance. There are three Risk Zones in Michigan: green (low CLS pressure with 1 to 2 fungicide applications per season), yellow (moderate CLS pressure with 2 to 3 fungicide applications per season), and red (high CLS pressure with 3 to 5 fungicide applications per season). Three trials per year have been conducted by Michigan Sugar Company to keep the BEETcast spray schedule up to date with these changing conditions and newer tolerant varieties. The objectives of this study were to (i) develop a conventional polymerase chain reaction (PCR) detection assay for QoI resistance in populations of C. beticola in eastern Michigan, (ii) employ a conventional PCR detection assay for benzimidazole resistance in populations of C. beticola in east-central Michigan, and (iii) determine the distribution of benzimidazole and QoI resistance in populations of $C$. beticola from CLS in sugarbeet production fields in Michigan.

\section{Materials and Methods}

Isolates and sampling. Leaves with symptoms of CLS were sampled from sugarbeet fields located in all three Cercospora Risk Zones in east-central Michigan during August and September of 2012. Samples of up to 15 leaf discs (depending on severity of symptoms and number of leaf spots) were taken at random from sugarbeet plants from throughout a selection of 115 fields in Michigan. Leaf discs $(5 \mathrm{~mm}$ ) were cut from leaves using a hole-punch). Global positioning system (GPS) coordinates of the field selected for sampling were recorded using a Mobile GPS Unit (Trimble Navigation Ltd., Sunnyvale, CA). The fields in Michigan were located in Arenac, Bay, Gratiot, Huron, Isabella, Midland, Saginaw, Sanilac, and Tuscola counties. The leaves were sent overnight to Michigan State University for evaluation. The leaves were refrigerated at $4^{\circ} \mathrm{C}$ (about $40^{\circ} \mathrm{F}$ ) until tested (maximum of 7 days after removal from the field).

Reference isolates of $C$. beticola known to be sensitive to benzimidazole and QoI fungicides from infected sugarbeet were maintained in pure culture on potato dextrose agar (Difco Inc., Detroit, MI). Survey samples collected from individual leaf spot lesions were grown on sugarbeet leaf extract agar (SBLEA, Ruppel). Fungicide sensitivity was determined using dilution plating or the spiral gradient dilution plate growth bioassay (14) on SBLEA amended with benzimidazole or with pyraclostrobin and salicylhydroxamic acid (SHAM) to block the alternate oxidation pathway (39). The effective concentration for $50 \%$ reduction in germination $\left(\mathrm{EC}_{50}\right)$ values for each isolate was calculated by regression analysis of percent spore germination versus the log fungicide concentration using Sigmaplot Version 9.01 (Systat Software, Chicago). The $\mathrm{EC}_{50}$ value of isolates that were QoI sensitive was $<0.01 \mu \mathrm{g} / \mathrm{ml}$ (26). Isolates from several counties in Michigan had uninhibited germination, and $\mathrm{EC}_{50}$ values for $\mathrm{QoI}$ fungicides exceeded the highest concentration tested $(100 \mu \mathrm{g} / \mathrm{ml})(26)$. The $\mathrm{EC}_{50}$ values of isolates that were benzimidazole sensitive were $<0.01 \mu \mathrm{g} / \mathrm{ml}$ (12). The $\mathrm{EC}_{50}$ values of benzimidazole-resistant isolates used in this study were $60 \mu \mathrm{g} / \mathrm{ml}$ or higher (12). DNA was extracted as described below. Isolates of $C$. beticola were sequenced at the Michigan State University Research Technology Support Facility using the BigDye3.1 Terminator sequencing kit (Applied Biosystems Inc., Foster City, CA) and analyzed on an ABI3730XL capillary sequencer (Applied Biosystems). The sequence of QoI-resistant $C$. beticola (26) had $100 \%$ identity to QoI-resistant isolates from GenBank (GenBank accession JQ619933 and JQ360628). The QoIsensitive isolate had $100 \%$ identity with a sensitive isolate (GenBank accession EF176921.1). Similarly, the sequence of benzimidazole-resistant $C$. beticola had $100 \%$ identity to benzimidazoleresistant isolates from GenBank (JQ619933 and JQ360628). Sequence results revealed that each resistant isolate contained a codon change that leads to a substitution of G143A, which confers QoI resistance in several other fungi. Benzimidazole-sensitive and -resistant $C$. beticola isolates had $100 \%$ identity with sequences for a benzimidazole-sensitive isolate (GenBank accession number AY856373) and a benzimidazole-resistant isolate (GenBank accession number AY856374), respectively (12).

DNA extraction. Frozen or fresh mycelia, in addition to mixed and unique lesion samples, were ground in liquid nitrogen using a mortar and pestle. Fungal DNA or DNA from sugarbeet leaf tissue field sampling was directly extracted using the Qiagen DNeasy Plant Mini Kit (Qiagen Inc., Valencia, CA) according to the manufacturers' instructions with slight modifications. For tissue disruption, the MP Biomedicals FastPrep Instrument (MP Biomedicals Inc., Solon, $\mathrm{OH}$ ) was used according to manufacturers' instructions. DNA was resuspended in $100 \mu \mathrm{l}$ of elution buffer and quantified using a spectrophotometer (ND-2000c, NanoDrop, Wilmington, DE).

PCR-based detection. Cytochrome b PCR-restriction fragment length polymorphism (RFLP) assay. PCR amplification targeted the $C$. beticola cytochrome $b$ gene. The previously described primer pair cytbFu 5'-ACAAAGCACCTAGAACATTGG-3' (33) and cytbRu 5'-GAAACTCCTAAAGGATTACCTGAACC-3' (33) was used to amplify a 325-bp amplicon from the cytochrome $b$ gene. Primers were synthesized by Integrated DNA Technologies, Inc. (Coralville, IA). PCR reactions consisted of: $3.0 \mu \mathrm{l}(\sim 30 \mathrm{ng})$ of genomic DNA template, $10 \mu \mathrm{l} 5 \times$ GoTaq Reaction Buffer with 7.5 $\mathrm{mM} \mathrm{MgCl} 2$ (Promega Co., Madison, WI), $1 \mu \mathrm{l}$ of $10 \mathrm{mM}$ dNTPs (Promega), $1.25 \mu \mathrm{l}$ of $10 \mu \mathrm{M}$ of each primer, and $1 \mu \mathrm{l}$ of $5 \mathrm{U} / \mu \mathrm{l}$ of Taq (GoTaq, Promega) in a $25-\mu \mathrm{l}$ reaction volume. Amplifications were performed on a thermocycler (MyCycler, Bio-Rad, Hercules, CA) using the following parameters: $95^{\circ} \mathrm{C}$ for $15 \mathrm{~min}$ followed by 28 cycles of $94^{\circ} \mathrm{C}$ for $30 \mathrm{~s}, 52^{\circ} \mathrm{C}$ for $30 \mathrm{~s}, 72^{\circ} \mathrm{C}$ for $45 \mathrm{~s}$, with a final 10 -min extension at $72^{\circ} \mathrm{C}$. PCR products were separated on $1 \%$ (wt/vol) agarose gel in $0.5 \times$ Tris-borate-EDTA (5.4 g Tris-base, $2.75 \mathrm{~g}$ Boric Acid, $2 \mathrm{ml} 0.5 \mathrm{M}$ EDTA, 1,000 ml $\mathrm{H}_{2} \mathrm{O}$ ) stained with GelRed Nucleic Acid Stain (Phenix Research Products, Chandler, NC) by electrophoresis and visualized by UV exposure using the Gel Doc 2000 apparatus (Bio-Rad).

Subsequent to PCR amplification, a $10-\mu$ l volume of the PCR reaction was digested overnight by $1.5 \mathrm{U}$ of Fnu4HI (New England Biolabs, Ipswich, MA) at $37^{\circ} \mathrm{C}$. Restriction fragments were separated on $2.5 \%$ agarose gels in $0.5 \times \mathrm{TBE}$ by electrophoresis, and stained with GelRed Nucleic Acid Stain. Gels were visualized using a UV transilluminator and documented using the Gel Doc 2000 apparatus. The PCR primers cytbFu and cytbRu amplify an 
325-bp fragment of the cytochrome $b$ gene containing codon 143 , the site of the G143A mutation. This point mutation changes the sequence $5^{\prime}$-GGTGC-3' to $5^{\prime}$-GCTGC- $3^{\prime}$, which is cleaved by the by the restriction endonuclease $F n u 4 \mathrm{HI}$ and confers resistance to QoI fungicides (31).

$\beta$-tubulin PCR-RFLP assay. PCR amplification targeted the $C$. beticola $\beta$-tubulin gene using a method briefly mentioned previously (37). The primer pair CbBtrF 5'-ATTCTCCGTCATGCC

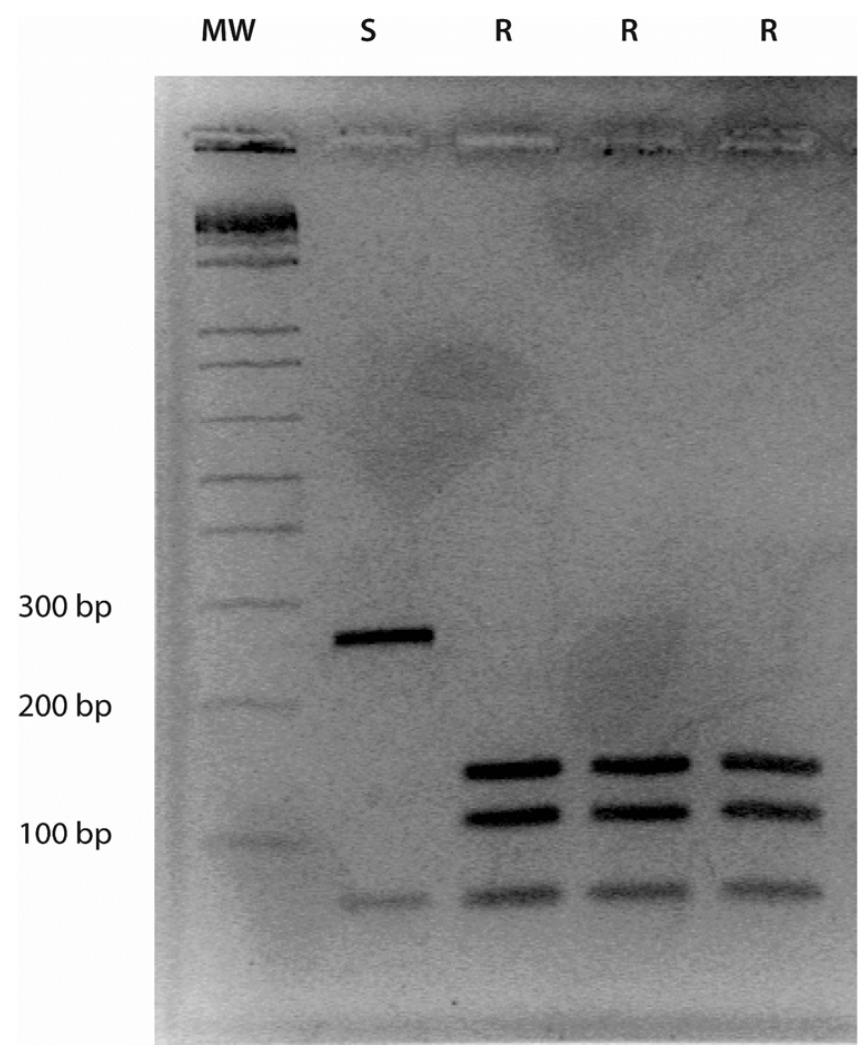

Fig. 1. Fnu4HI restriction pattern of a 325-bp-long fragment of the cytochrome $b$ gene including the site of the resistance-associated mutation in sensitive (S) and resistant $(R)$ isolates of Cercospora beticola (lanes 2 to 5 , from left to right) show the digestion pattern. The first lane (MW) on the left represents the size of standards based on a 100-bp plus DNA ladder.
ATCTC-3' and CbBtrR 5'-GAAACGCAGACAGGTTGTCA-3' was used to amplify a 500-bp amplicon from the $\beta$-tubulin gene. Primers were synthesized by Integrated DNA Technologies. PCR reactions were carried out in $20-\mu l$ reaction volumes as described above. PCR amplifications were performed with the following parameters: initial denaturation of $94^{\circ} \mathrm{C}$ for $5 \mathrm{~min}, 35$ cycles of $94^{\circ} \mathrm{C}$ for $1 \mathrm{~min}, 52^{\circ} \mathrm{C}$ for $30 \mathrm{~s}$, and $72^{\circ} \mathrm{C}$ for $1 \mathrm{~min}$, with a final extension at $72^{\circ} \mathrm{C}$ for $5 \mathrm{~min}$. Subsequently, PCR products were separated and visualized as describe above.

Subsequent to PCR amplification, a 10- $\mu$ l volume of the PCR reaction was digested overnight by $1.5 \mathrm{U}$ of Bst $\mathrm{UI}$ (New England Biolabs) at $37^{\circ} \mathrm{C}$. Restriction fragments were separated and visualized as described above. The PCR primers $\mathrm{CbBtrF}$ and $\mathrm{CbBtrR}$ are designed to amplify an 500-bp $\beta$-tubulin gene fragment containing codon 198, the site of the E198A mutation (34). This point mutation changes the sequence $5^{\prime}$-CGCG-3' to 5'-GCGC-3', which is cleaved by the restriction endonuclease $B s t \mathrm{UI}$ and confers a high level of resistance to benzimidazoles $(31,32)$.

Detection thresholds of PCR assays. Total genomic DNA extracted from a QoI- or benzimidazole-sensitive $C$. beticola fungal isolate was mixed at different ratios with DNA extracted from a QoI- or benzimidazole-resistant isolate with either a G143A or E198A mutation, respectively. The ratios tested ranged from 99:1 to 60:40 (sensitive:resistant). PCR-RFLP assays were performed as described above using $3 \mathrm{ng}$ of mixed DNA samples as template for amplification.

Distribution of benzimidazole and QoI resistance in populations of $\boldsymbol{C}$. beticola. ArcGIS professional suite of Geographic Information System (ESRI, Redlands, CA) was used to map the distribution of benzimidazole and QoI resistance in populations of $C$. beticola from commercial sugarbeet production fields. ArcGIS Desktop (ver. 9.3.1) was used for spatial analyses and map drawings for benzimidazole and QoI resistance mutations in $C$. beticola in Michigan.

The sugarbeet fields sampled were corresponded to the longitude and latitude coordinates obtained from Michigan Sugar Company's crop records database system. The longitude and latitude coordinates of the sampled areas were separated by insensitive and sensitive isolates obtained from PCR-RFLP detection assay described above, and the coordinates were inserted into a Microsoft Excel spreadsheet and converted and displayed as $\mathrm{XY}$ data in ArcView. Digital map images were converted into .jpg files, and additional editing was done using Adobe Illustrator CS4 (Adobe Systems Inc., San Jose, CA).

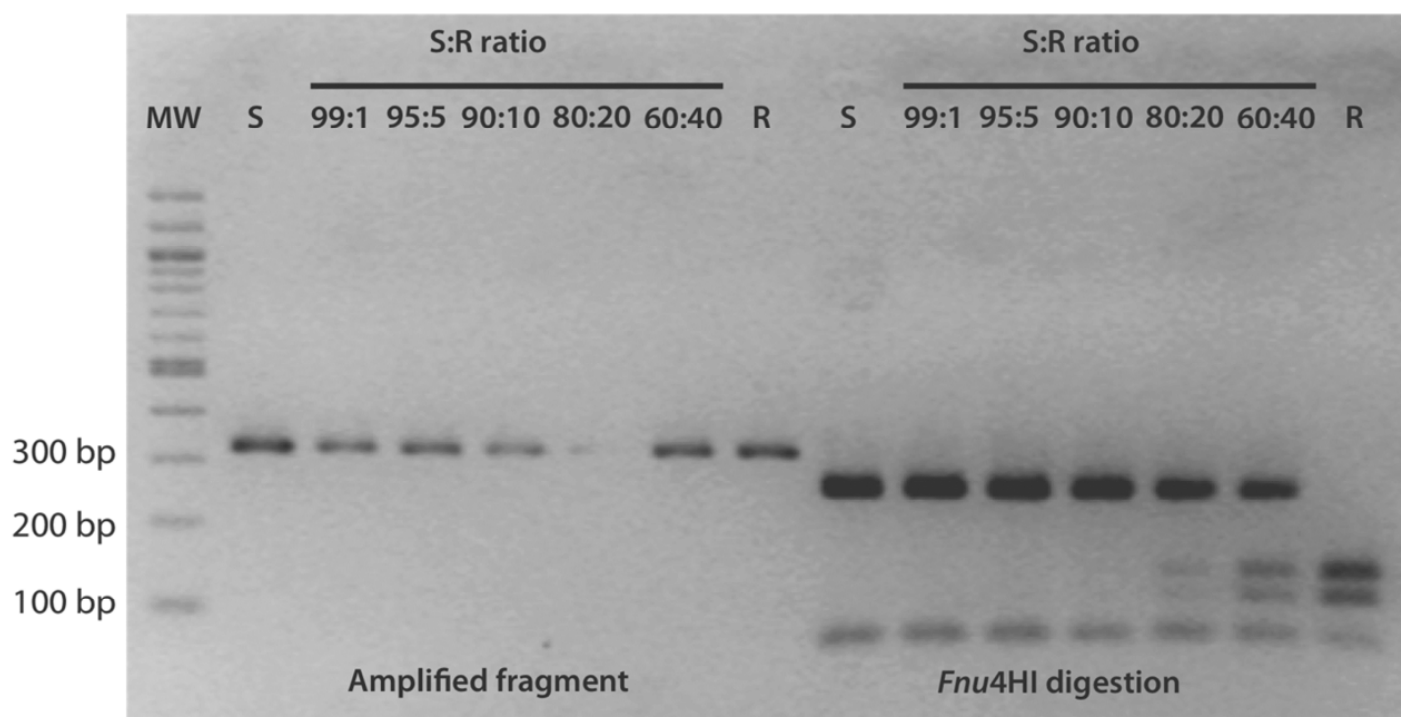

Fig. 2. Sensitivity of the allele-specific PCR restriction fragment length polymorphism (RFLP) method. DNA extracted from Qol-sensitive (S) and -resistant (R) isolates were mixed at different ratios (from 1:99 to 60:40) prior to PCR of the 325-bp-long amplified fragment of the cytochrome $b$ gene. The $100 \%$ sensitive (S) and $100 \%$ resistant (R) corresponded to DNA extracted from mycelium of a Qol-sensitive isolate and a Qol-resistant isolate, respectively. Size of standards based on a 100-bp DNA ladder (MW). 


\section{Results}

PCR-based detection. PCR-based detection of the G143A mutation in C. beticola. The molecular based PCR-RFLP method was successful in detecting the isolates insensitive to QoI fungicides directly from both genomic DNA and DNA extracted from leaf tissue. This method results in the digestion of PCR products with a restriction enzyme (Fnu4HI) that cleaves the PCR amplified fragment at the site of the mutation responsible for fungicide insensitivity (Figs. 1 to 3 ). Subsequent to digestion with this enzyme, three DNA fragments were obtained with the PCR fragment from the resistant isolate, whereas the PCR product from the sensitive isolate was cleaved twice (Figs. 1 to 3 ). The sensitivity of the QoI PCR-RFLP protocol was evaluated by amplifying cytochrome $b$ mutant allele DNA molecules when mixed at different ratios with wild-type allele molecules. The mutant allele (conferring QoI resistance) was amplified at a ratio of 20 to $60 \%$ from the DNA extracted from CLS-infected leaves (Fig. 2).

PCR-based detection of the E198A mutation in C. beticola. Similar to the QoI DNA-based PCR assay, the benzimidazole PCR-RFLP method was successful in detecting the isolates insensitive to benzimidazole fungicides directly from both genomic DNA (data not shown) and DNA extracted from leaf tissue (Supplementary Figure 1). This method results in the digestion of PCR products with a restriction enzyme (BtsUI) that cleaves the PCR-amplified fragment at the site of the mutation responsible for fungicide insensitivity. After digestion with BtsUI, two DNA fragments are obtained from a resistant isolate, whereas a sensitive isolate is not cut. The sensitivity of the QoI PCR-RFLP protocol was evaluated by amplifying $\beta$-tubulin gene mutant allele DNA molecules when mixed at different ratios with wild-type allele molecules. Similar to the QoI assay, the benzimidazole mutant allele was amplified at a ratio of at least 20:60 (resistant:sensitive) (data not shown).

Predominance of G134A and E198A mutations in C. beticola populations in Michigan sugarbeet production fields in 2012. During the 2012 growing season, 102 production fields were sampled for $C$. beticola using sugarbeet leaves showing symptoms of CLS (Table 1). These production fields were located in eight counties in the east-central Michigan sugarbeet production region (Figs. 4 and 5). A total of 123 samples (615 lesions) were processed us- ing the PCR-RFLP detection method for both QoI and benzimidazole fungicide resistance mutations (Table 1). A high proportion of samples ( 94\%) from commercial growing regions that were screened in 2012 were found to contain the G143A mutation by PCR-RFLP detection (Table 1). Similarly, a high proportion of samples $(\sim 97 \%)$ from fields with resistant:sensitive mixtures were found to contain the E198A mutation by PCR-RFLP detection (Table 1). Wild-type (sensitive) mutations were detected in samples from two counties (Gratiot and Huron) and three counties (Gratiot, Huron, and Saginaw) using the G134A and the E198A detection methods, respectively (Figs. 4 and 5).

\section{Discussion}

CLS continues to be a disease of concern for sugarbeet production in Michigan, especially during growing seasons when environmental conditions favor disease progression. Due to significant

Table 1. Summary of Cercospora beticola monitoring effort from Michigan commercial sugarbeet fields in 2012, number of production fields sampled, results from PCR-based detection methods, total samples processed, and total leaves used in DNA assay

\begin{tabular}{lcc}
\hline & $\begin{array}{c}\text { Benzimidazole } \\
\text { detection assay }^{\mathbf{a}}\end{array}$ & QoI detection assay ${ }^{\mathbf{b}}$ \\
\hline Production fields & 102 & 102 \\
Resistant & $98(80 \%)^{\mathrm{c}}$ & $82(67 \%)^{\mathrm{c}}$ \\
Mixed 50:50 & 4 & 6 \\
Mixed/resistant & 3 & 21 \\
Mixed/sensitive & 3 & 4 \\
Sensitive & 3 & 7 \\
Total samples & 123 & 123 \\
Total leaves & 615 & 615 \\
\hline
\end{tabular}

a Assay based on PCR amplification and subsequent enzymatic cleavage using BstUI restriction enzyme to detect the E198A mutation in the Cercospora beticola $\beta$-tubulin gene that confers resistance to benzimidazole fungicides.

${ }^{\mathrm{b}}$ Assay based on PCR amplification and subsequent enzymatic cleavage using Fnu4HI restriction enzyme to detect the G143A mutation in the Cercospora beticola cytochrome $b$ gene that confers resistance to Quinone outside inhibitor (QoI) fungicides.

${ }^{\mathrm{c}}$ Percentage based samples where only resistant mutations were detected from the field.

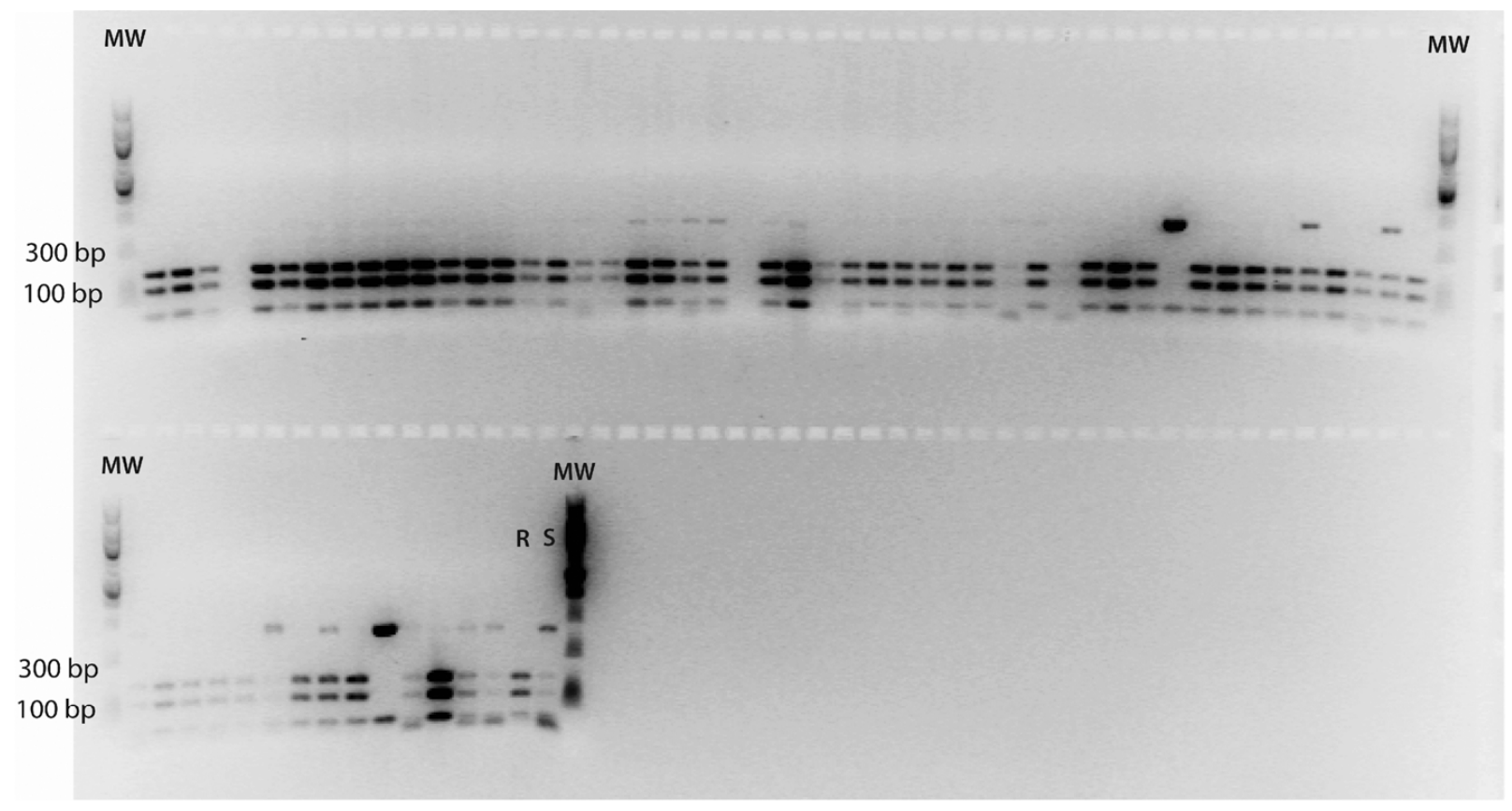

Fig. 3. Fnu4HI restriction pattern of a fragment of the cytochrome $b$ gene including the site of mutation in Qol-sensitive (S) and -resistant (R) Cercospora beticola. Size of standards based on a 100-bp DNA ladder (MW). Remaining lanes contain DNA isolated directly from Beta vulgaris leaves symptomatic of Cercospora leaf spot from commercial production fields. 
economic barriers preventing sugarbeet growers in Michigan from applying more than three fungicide applications to control CLS, and a tendency to apply products with narrow modes of action and a single active ingredient (e.g., pyraclostrobin and benzimidazole), there is concern for the development of fungicide resistant populations and loss of efficacy of certain chemistries. This project was designed to develop information needed to augment current sugarbeet disease and crop management systems, with a focus on detecting and monitoring fungicide resistant populations of $C$. beticola causing CLS in Michigan commercial production. The information generated from this study is essential for the evaluation of integrated management strategies for the control of CLS in Michigan with an emphasis on fungicide resistance management.

The mode of resistance to QoI fungicides is well established, and the presence of point mutations in the cytochrome $b$ gene has been reported in both $C$. beticola $(4,26,33)$ and a range of plant pathogenic fungi and fungal-like organisms including $M$. fijiensis, $V$. inaequalis, P. aphanidermatum, A. solani, P. grisea, C. graminicola, S. fuliginea, P. cubensis, and P. viticola $(1,2,8,20,28,38$, $40,42,43)$. Similarly, this study confirmed the widespread presence of the G143A point mutation in populations of $C$. beticola causing CLS in Michigan commercial production sugarbeet fields. This is in contrast to $C$. beticola laboratory mutants resistant to QoI fungicides where, at a point mutation at position 143, alanine is changed to serine (G143S) (33). The presence of a single point mutation causing QoI resistance enables the development of rapid DNA-based detection methods for monitoring plant pathogen populations. Molecular based DNA approaches to detect single nucleotide polymorphisms (SNP) responsible for QoI resistance have been used successfully in A. solani, C. beticola, E. grisea, Monilinia laxa, P. aphanidermatum, and $V$. inaequalis $(1,4,13,33,40$,
$42,43,45)$, and a method using real time PCR has been proposed for $C$. beticola (3). The current study demonstrates the utility of a rapid PCR-RFLP method to both detect the G143A mutation responsible for QoI resistance in Michigan and its application for monitoring of $C$. beticola in field populations. Such a method is readily usable by diagnostic clinics. Taken together, this will enable the future monitoring of $C$. beticola populations from commercial sugarbeet production areas in Michigan, in addition to evaluating the efficacy of current recommended fungicide management strategies for CLS.

C. beticola has no known sexual stage, although sexual reproduction is hypothesized to occur in some areas based on genetic studies $(17,18)$. While sexual reproduction may be occurring, a correlation between levels of asexual conidia and disease severity has been reported in the United States (25), and incidence of CLS has been reported to be higher close to where beets have been grown the previous year (36) and has been reported to be primarily from overwintering asexual forms $(24,36)$. While sexual reproduction, if it occurs, could factor into dissemination of fungicide resistance in $C$. beticola, at present its role, if any, is unknown.

The mechanism responsible for benzimidazole resistance is known. The presence of SNPs in the $\beta$-tubulin gene at position 198 has been identified in a number of plant pathogenic fungi including Monilinia fructicola, Botrytis cinerea, Sclerotinia homoeocarpa, and $V$. inaequalis $(27,30,32,35)$. More recently, a PCR-RFLP method has been developed to detect the E198A mutation conferring resistance to benzimidazole fungicides in field isolates of $M$. laxa (34). The DNA based diagnostic was successful in discriminating $M$. laxa benzimidazole-resistant from -sensitive genotypes. Moreover, studies on the analysis of $\beta$-tubulin gene fragments from benzimidazole-sensitive and -tolerant $C$. beticola determined that

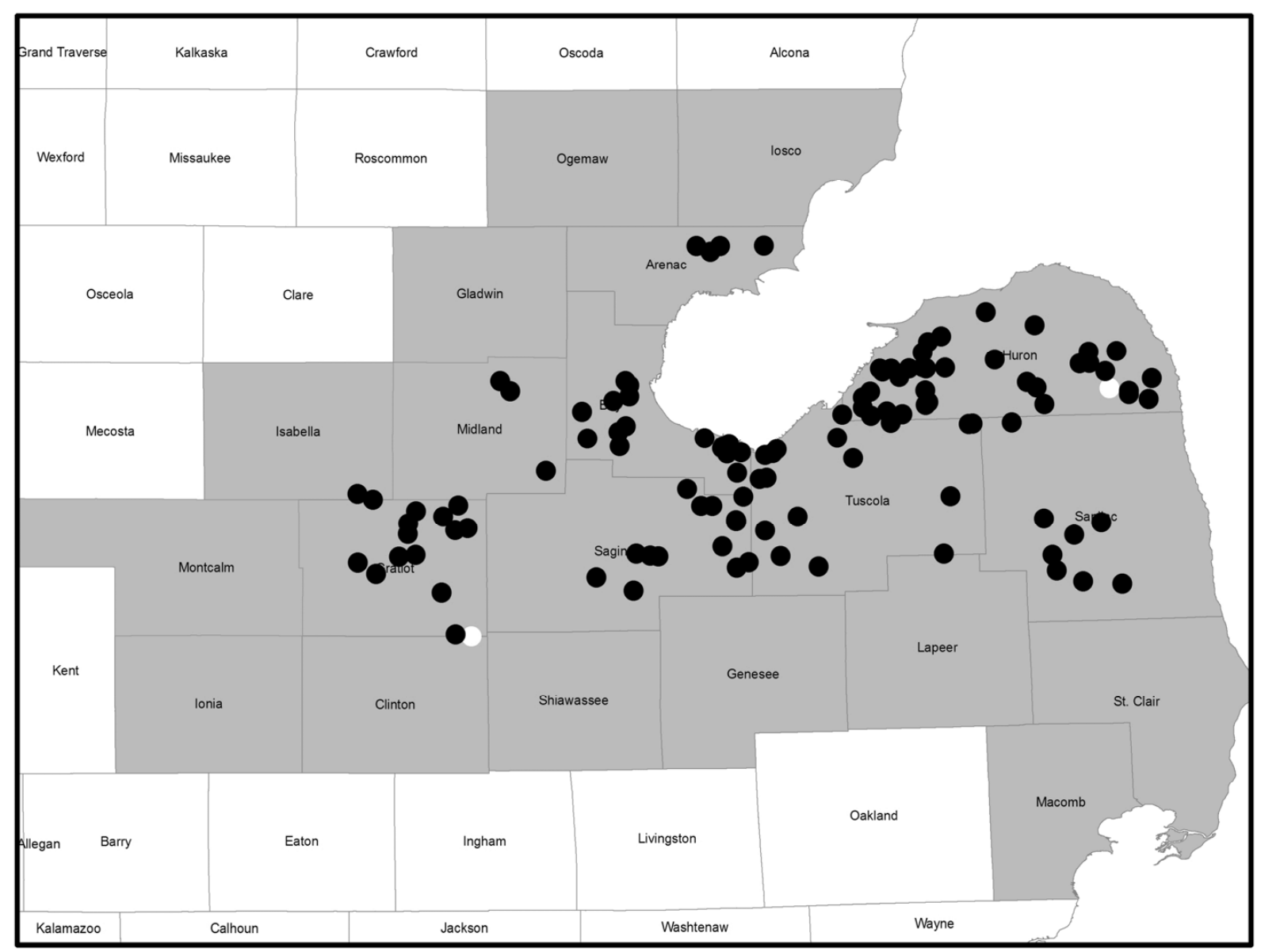

Fig. 4. Distribution of the G143A mutation in the cytochrome $b$ gene detected by PCR-based methods in Michigan Cercospora beticola populations sampled from 2012. Shaded counties represent areas of commercial sugarbeet production. The county names are shown within the border: - represents detection of Qol-resistant isolates; $O$ represents detection of Qol-sensitive isolates. 
the same E198A mutation was responsible for resistance to benzimidazole fungicides (12). Similarly, this study used a PCR-RFLP method to detect the E198A mutation responsible for benzimidazole resistance in C. beticola field populations from Michigan. A similar method has been tested recently in Serbia, where more than one resistance mutation has been identified (47).

The reduced availability of effective chemical fungicides for plant disease management, the evolution of fungicide resistant populations, and the U.S. EPA restrictions on continued use of select chemistries, necessitates the development, evaluation, and deployment of effective resistance management programs. The DNA-based methods used in this study will enable testing of resistant management strategies as a component for integrated management in sugarbeet production. Moreover, the use of PCR-based detection methods has already been shown to be an effective tool in evaluating resistant management programs and label recommendations for the control of early blight of potato caused by $A$. solani (42).

During the 2011 growing season, insensitivity to QoI fungicides was identified in Michigan isolates of $C$. beticola as the cause of CLS (26). Insensitivity was associated with loss of disease control in some fields and was due to the G143A mutation in the cytochrome $b$ gene. This monitoring study found that during the 2012 season, mutations in the cytochrome $b$ gene were widespread in sugarbeet production areas in Michigan. Therefore, continued monitoring is important for the effective use of QoI fungicides.

From the information generated in this study, we have validated two molecular based PCR-RFLP methods to detect the isolates insensitive to QoI and benzimidazole fungicides. These methods result in three and two genetic markers, indicating SNPs at position 143 in the cytochrome $b$ gene, and 198 in the $\beta$-tubulin gene, re- spectively. These assays enable a simple conventional PCR detection of $C$. beticola isolates insensitive to QoI and benzimidazole fungicides in less than 24 hours. Both assays are limited by a threshold of detection of $20 \%$ of the resistant allele in mixed populations.

This study found that although QoIs and benzimidazoles are used in sugarbeet disease management, the majority of samples recovered from production fields contained SNP mutations conferring resistance to these active ingredients. In 2010 and 2013, 40 and $21 \%$ and 1 and $0.5 \%$ of growers applied a QoI and a benzimidazole fungicide, respectively. The reason for the decrease in QoI and benzimidazole applications was due to the insensitivity to these classes of fungicides (confirmed in 2011), along with a Michigan Sugar Company resistance management program that didn't recommend these fungicide classes. These numbers were obtained from Michigan Sugar Company Crop Record Database System. QoI and benzimidazole fungicides are not recommended for use in areas where resistance has been reported. However, if growers insist on using either active ingredient, for example for control of Rhizoctonia crown and root rot, then these products should be used early in the development of the crop (up to leaf stage 6 to 8 ) and then in mixture with a residual protectant fungicide such as an EBDC. In CLS management programs, these materials may be used at the growers risk and tank-mixed with an EBDC and applied between triazole applications. Therefore, if sugarbeet growers decide to continue using a QoI fungicide, it is recommended to (i) continue to monitor field populations for SNP mutations responsible for fungicide resistance; (ii) limit the number of QoI applications during a season; (iii) never apply consecutive applications of chemicals with same mode of action; (iv) apply QoI fungicides early in the growing season alternated (no consecu-

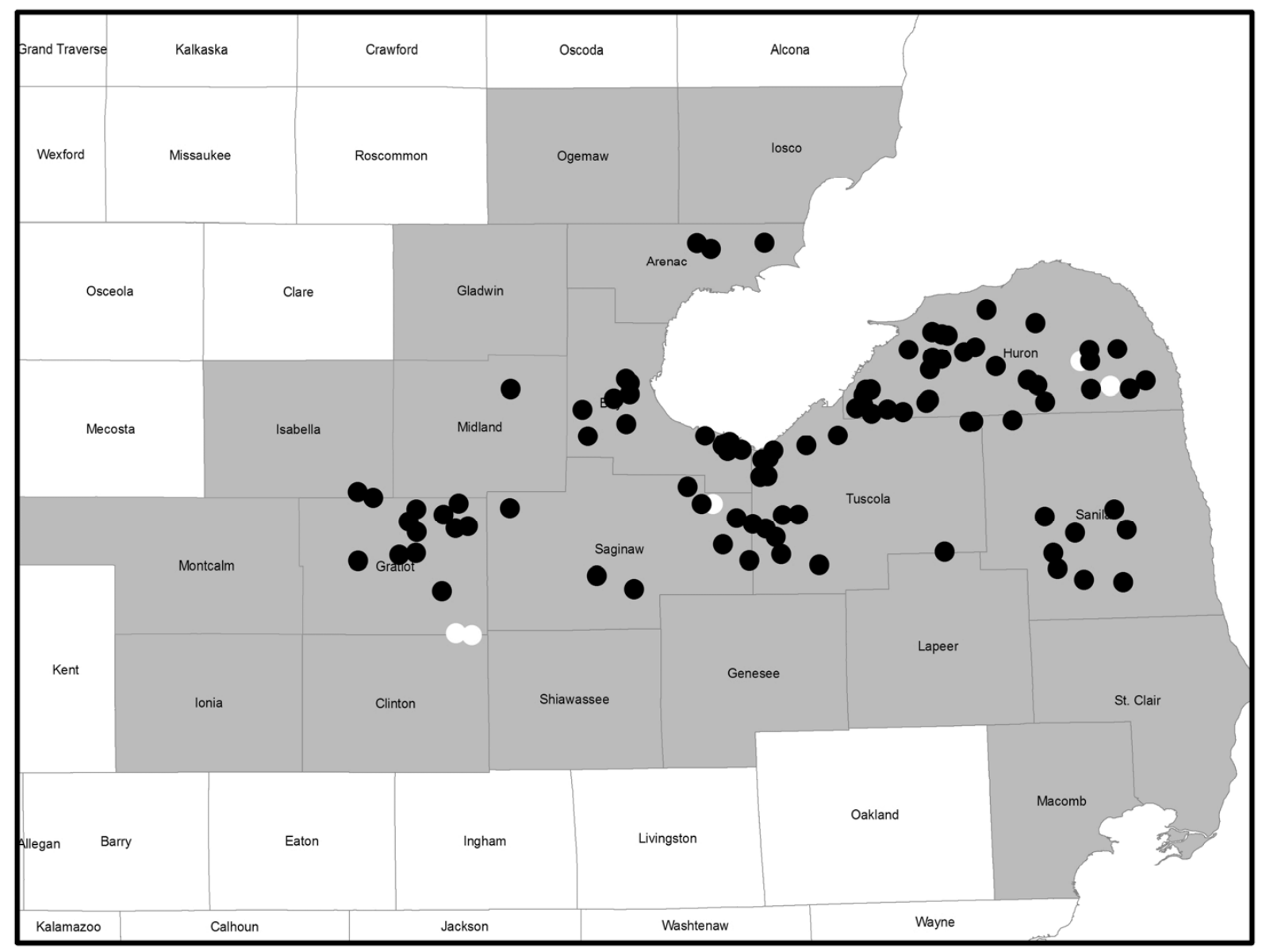

Fig. 5. Distribution of the E198A mutation in the $\beta$-tubulin detected by PCR-based methods in Michigan Cercospora beticola populations sampled from 2012. Shaded counties represent areas of commercial sugarbeet production. The county names are shown within the border: $\mathrm{represents} \mathrm{detection} \mathrm{of} \mathrm{benzimidazole-resistant} \mathrm{isolates;} \bigcirc$ represents detection of benzimidazole-sensitive isolates. 
tive applications), tank mixed, or, when available, as prepack mixes with compounds of different chemistries; and (v) never use QoI fungicides in a curative manner. Moreover, subsequent to this study during the 2012 growing season, several studies reported using molcecular SNP detection methods (e.g., PCR-RFLP and real-time PCR) in C. beticola $(3,4,47)$. Despite the widespread occurrence of the E198A mutation, no complete product failures have been reported to date. This is in contrast to a recent study in Serbia that found some moderate resistance with a F167Y SNP mutation in the $\beta$-tubulin gene (47). The use of products belonging to different cross-resistance groups will likely be effective in the continued efficacy of chemical management strategies for CLS. The PCRRFLP diagnostics used in this study will provide an effective tool in the high throughput processing of samples to evaluate effective fungicide resistance management strategies for CLS. Moreover, a PCR-RFLP diagnostic requires minimal start-up cost compared to real-time PCR methods (e.g., thermocycler, primers, and fluorescent probes).

\section{Acknowledgments}

In memory of Gary D. Franc, who died too soon, October 2012. This project was partially supported by the Michigan Sugar Company Research \& Education Advisory Council and the Michigan State University Project GREEEN (Generating Research and Extension to Meet Economic and Environmental Needs) and CSREES Hatch Project Number MICL01966. The authors thank all the agriculturists from Michigan Sugar Company that assisted in collection of samples. Mention of trade names or commercial products in this article is solely for the purpose of providing specific information and does not imply recommendation or endorsement.

\section{Literature Cited}

1. Avila-Cruz, A., Olaya, G., and Koller, W. 2003. Characterization of Colletotrichum graminicola isolates resistant to strobilurin-related QoI fungicides. Plant Dis. 87:1426-1432.

2. Bartlett, D. W., Clough, J. M., Godwin, J. R., Hall, A. A., Hamer, M., and Parr-Dobrzanski, B. 2002. The strobilurin fungicides. Pest Manage. Sci. 58:649-662.

3. Bolton, M., Rivera, V., and Secor, G. 2012. Identification of the G143A mutation associated with QoI resistance in Cercospora beticola field isolates from Michigan, United States. Pest Manage. Sci. 69:35-39.

4. Bolton, M., Rivera-Varas, V., Secor, G., Cattanach, A., and Metzger, M. 2013. Identification of the G143A mutation in cytochrome b associated with QoI resistance in Cercospora beticola isolates from the Red River Valley. Plant Health Progress 10.

5. Bolton, M. D., Rivera-Varas, V., del Río Mendoza, L. E., Khan, M. F., and Secor, G. A. 2012. Efficacy of variable tetraconazole rates against Cercospora beticola isolates with differing in vitro sensitivities to DMI fungicides. Plant Dis. 96:1749-1756.

6. Bugbee, W. 1995. Cercospora beticola tolerant to triphenyltin hydroxide. J. Sugar Beet Res. 32:167-174.

7. Campbell, L., Smith, G., Lamey, H., and Cattanach, A. 1998. Cercospora beticola tolerant to triphenyltin hydroxide and resistant to thiophanate methyl in North Dakota and Minnesota. J. Sugar Beet Res. 35:29-41.

8. Chin, K. M., Chavaillaz, D., Kaesbohrer, M., Staub, T., and Felsenstein, F. G. 2001. Characterizing resistance risk of Erysiphe graminis f.sp. tritici to strobilurins. Crop Prot. 20:87-96

9. Cooley, R., and Caten, C. 1993. Molecular analysis of the Septoria nodorum $\beta$-tubulin gene and characterization of a benomyl-resistance mutation. Mol. Gen. Genet. 237:58-64.

10. Davidse, L., and Flach, W. 1977. Differential binding of methyl benzimidazol-2-yl carbamate to fungal tubulin as a mechanism of resistance to this antimitotic agent in mutant strains of Aspergillus nidulans. J. Cell Biol. 72:174-193.

11. Davidse, L. C. 1986. Benzimidazole fungicides: Mechanism of action and biological impact. Annu. Rev. Phytopathol. 24:43-65.

12. Davidson, R., Hanson, L., Franc, G., and Panella, L. 2006. Analysis of $\beta$ tubulin gene fragments from benzimidazole-sensitive and -tolerant Cercospora beticola. J. Phytopathol. 154:321-328.

13. Fontaine, S., Remuson, F., Fraissinet-Tachet, L., Micoud, A., Marmeisse, R., and Melayah, D. 2009. Monitoring of Venturia inaequalis harbouring the QoI resistance G143A mutation in French orchards as revealed by PCR assays. Pest Manage. Sci. 65:74-81.

14. Forster, H., Kanetis, L., and Adaskaveg, J. 2004. Spiral gradient dilution, a rapid method for determining growth responses and $50 \%$ effective concentration values in fungus-fungicide interactions. Phytopathology 94:163-170.

15. Franc, G. 2010. Ecology and epidemiology of Cercospora beticola. American Phytopathological Society, St. Paul, MN.

16. Gisi, U., Chin, K. M., Knapova, G., Farber, R. K., Mohr, U., Parisi, S., Sierotzki, H., and Steinfeld, U. 2000. Recent developments in elucidating modes of resistance to phenylamide, DMI and strobilurin fungicides. Crop Prot. 19:863-872.

17. Groenewald, M., Groenewald, J. Z., Harrington, T. C., Abeln, E. C., and Crous, P. W. 2006. Mating type gene analysis in apparently asexual Cercospora species is suggestive of cryptic sex. Fungal Genet. Biol. 43:813-825.

18. Groenewald, M., Linde, C., Groenewald, J., and Crous, P. 2008. Indirect evidence for sexual reproduction in Cercospora beticola populations from sugar beet. Plant Pathol. 57:25-32.

19. Hanson, L., Davidson, R., Franc, G., and Panella, L. 2005. Analysis of benzimidazole-tolerance in Cercospora beticola. American Society of Sugarbeet Technologists: 179 .

20. Ishii, H., Fraaije, B. A., Sugiyama, T., Noguchi, K., Nishimura, K., Takeda, T., Amano, T., and Hollomon, D. W. 2001. Occurrence and molecular characterization of strobilurin resistance in cucumber powdery mildew and downy mildew. Phytopathology 91:1166-1171.

21. Jacobsen, B., and Franc, G. 2009. Cercospora leaf spot. American Phytopathological Society, St. Paul, MN.

22. Jung, M., Wilder, I., and Oakley, B. 1992. Amino acid alterations in the benA ( $\beta$-tubulin) gene of Aspergillus nidulans that confer benomyl resistance. Cell Motil Cytoskel. 22:170-174.

23. Kaiser, U., Kluth, C., and Marlander, B. 2010. Variety-specific epidemiology of Cercospora beticola Sacc. and consequences for thresholdbased timing of fungicide application in sugar beet. J. Phytopathol. 158:296-306.

24. Khan, J., Del Rio, L., Nelson, R., and Khan, M. 2007. Improving the Cercospora leaf spot management model for sugar beet in Minnesota and North Dakota. Plant Dis. 91:1105-1108.

25. Khan, J., Qi, A., and Khan, M. 2009. Fluctuations in number of Cercospora beticola conidia in relationship to environment and disease severity in sugar beet. Phytopathology 99:796-801.

26. Kirk, W., Hanson, L., Franc, G., Stump, W., Gachango, E., Clark, G., and Stewart, J. 2012. First report of strobilurin resistance in Cercospora beticola in sugarbeet Beta vulgaris in Michigan and Nebraska, USA. New Dis. Rep. 26:3.

27. Koenraadt, H., Somerville, S. C., and Jones, A. 1992. Characterization of mutations in the beta-tubulin gene of benomyl-resistant field strains of Venturia inaequalis and other plant pathogenic fungi. Phytopathology 82:1348-1354.

28. Küng Färber, R., Chin, K. M., and Leadbitter, N. 2002. Sensitivity of Venturia inaequalis to trifloxystrobin. Pest Manage. Sci. 58:261-267.

29. Leroux, P., Fritz, R., Debieu, D., Albertini, C., Lanen, C., Bach, J., Gredt, M., and Chapeland, F. 2002. Mechanisms of resistance to fungicides in field strains of Botrytis cinerea. Pest Manage. Sci. 58:876-888.

30. Luck, J. E., and Gillings, M. R. 1995. Rapid identification of benomyl resistant strains of Botrytis cinerea using the polymerase chain reaction. Mycol. Res. 99:1483-1488.

31. Ma, Z., and Michailides, T. 2005. Advances in understanding molecular mechanisms of fungicide resistance and molecular detection of resistant genotypes in phytopathogenic fungi. Crop Prot. 24:853-863.

32. Ma, Z., Yoshimura, M. A., and Michailides, T. J. 2003. Identification and characterization of benzimidazole resistance in Monilinia fructicola from stone fruit orchards in California. Appl. Environ. Microbiol. 69:7145-7152.

33. Malandrakis, A., Markoglou, A., Nikou, D., Vontas, J., and Ziogas, B. 2011 Molecular diagnostic for detecting the cytochrome $b$ G143S - QoI resistance mutation in Cercospora beticola. Pestic. Biochem. Physiol. 100:87-92.

34. Malandrakis, A. A., Markoglou, A. N., and Ziogas, B. N. 2012. PCR-RFLP detection of the E198A mutation conferring resistance to benzimidazoles in field isolates of Monilinia laxa from Greece. Crop Prot. 39:11-17.

35. McKay, G. J., and Cooke, L. R. 1997. A PCR-based method to characterise and identify benzimidazole resistance in Helminthosporium solani. FEMS Microbiol. Lett. 152:371-378.

36. McKay, M. B., and Pool, V. W. 1918. Field studies of Cercospora beticola. Phytopathology 8:119-136.

37. Obuya, J., Hanson, L., Stump, W., and Franc, G. 2008. A rapid diagnostic tool for detecting benzimidazole resistance in Cercospora beticola, the causal agent of Cercospora leaf spot in sugarbeet. (Abstr.) Pytopathology 98:S115.

38. Olaya, G., Cleere, S., Stanger, C., Burbidge, J., Hall, A., and Windass, J. 2003. A novel potential target site of QoI fungicide resistance mechanism in Pythium aphanidermatum. (Abstr.) Phytopathology 93:S67.

39. Olaya, G., Zheng, D., and Koller, W. 1999. Differential responses of germinating Venturia inaequalis conidia to kresoxim-methyl. Pestic. Sci. 54:230-236.

40. Pasche, J. S., Piche, L. M., and Gudmestad, N. C. 2005. Effect of the F129L mutation in Alternaria solani on fungicides affecting mitochondrial respiration. Plant Dis. 89:269-278.

41. Reijo, R. A., Cooper, E. M., Beagle, G. J., and Huffaker, T. C. 1994 Systematic mutational analysis of the yeast beta-tubulin gene. Mol. Biol. Cell 5:29.

42. Rosenzweig, N., Atallah, Z., Olaya, G., and Stevenson, W. 2008. Evaluation of QoI fungicide application strategies for managing fungicide resistance and potato early blight epidemics in Wisconsin. Plant Dis. 92:561-568. 
43. Rosenzweig, N., Olaya, G., Atallah, Z., Cleere, S., Stanger, C., and Stevenson, W. 2008. Monitoring and tracking changes in sensitivity to azoxystrobin fungicide in Alternaria solani in Wisconsin. Plant Dis. 92:555-560.

44. Sauter, H., Steglich, W., and Anke, T. 1999. Strobilurins: Evolution of a new class of active substances. Angewandte Chemie International Edition 38:1328-1349.

45. Sierotzki, H., Wullschleger, J., and Gisi, U. 2000. Point mutation in cytochrome $\mathrm{b}$ gene conferring resistance to strobilurin fungicides in Erysiphe graminis f. sp. tritici field isolates. Pestic. Biochem. Physiol. 68:107-112.

46. Sisler, H. 1988. Fungicidal action and fungal resistance mechanisms. In: Fungicide Resistance in North America. C. J. Delp, ed. American Phytopathological Society, St. Paul, MN.
47. Trkulja, N., Ivanović, Ž., Pfaf-Dolovac, E., Dolovac, N., Mitrović, M. Toševski, I., and Jović, J. 2013. Characterisation of benzimidazole resistance of Cercospora beticola in Serbia using PCR-based detection of resistance-associated mutations of the $\beta$-tubulin gene. Eur. J. Plant Pathol 135:889-902.

48. Weiland, J., and Halloin, J. 2001. Benzimidazole resistance in Cercospora beticola sampled from sugarbeet fields in Michigan, USA. Can. J. Plant Pathol. 23:78-82.

49. Windels, C., Lamey, H., Hilde, D., Widner, J., and Knudsen, T. 1998. A Cerospora leaf spot model for sugar beet: In practice by an industry. Plant Dis. 82:716-726.

50. Yarden, O., and Katan, T. 1993. Mutations leading to substitutions at amino acids 198 and 200 of beta-tubulin that correlate with benomyl-resistance phenotypes of field strains of Botrytis cinerea. Phytopathology 83:1478-1483. 